\title{
Nano-titanium dioxide modulates the dermal sensitization potency of DNCB
}

\author{
Salik Hussain ${ }^{1,2,4+}$, Stijn Smulders ${ }^{2 \dagger}$, Vanessa De Vooght ${ }^{2}$, Bert Ectors ${ }^{2}$, Sonja Boland ${ }^{1}$, Francelyne Marano ${ }^{1}$, \\ Kirsten L Van Landuyt ${ }^{3}$, Benoit Nemery ${ }^{2}$, Peter HM Hoet ${ }^{2}$ and Jeroen AJ Vanoirbeek ${ }^{2^{*}}$
}

\begin{abstract}
We determined the ability of a model nanoparticle (NP) (titanium dioxide, $\mathrm{TiO}_{2}$ ) to modulate sensitization induced by a known potent dermal sensitizer (dinitrochlorobenzene) using a variant of the local lymph node assay called lymph node proliferation assay.

$\mathrm{BALB} / \mathrm{c}$ mice received sub-cutaneous injections of vehicle (2.5 mM sodium citrate), $\mathrm{TiO}_{2} \mathrm{NPs}(0.004,0.04$ or $0.4 \mathrm{mg} /$ $\mathrm{ml}$ ) or pigment particles $(0.04 \mathrm{mg} / \mathrm{ml})$ both stabilized in sodium citrate buffer at the base of each ear $(2 \times 50 \mu \mathrm{l})$, before receiving dermal applications (on both ears) of 2,4-Dinitrochlorobenzene (DNCB) $(2 \times 25 \mu$ l of $0.1 \%)$ or its vehicle (acetone olive oil - AOO (4:1)) on days 0,1 and 2 . On day 5, the stimulation index (SI) was calculated as a ratio of ${ }^{3} \mathrm{HTdR}$ incorporation in lymphocytes from DNBC-treated mice and AOO-treated controls. In a second experiment the $\mathrm{EC}_{3}$-value for DNCB (0 to $0.1 \%$ ) was assessed in the absence or presence of $0.04 \mathrm{mg} / \mathrm{ml} \mathrm{TiO}_{2}$. In a third experiment, the lymphocyte subpopulations and the cytokine secretion profile were analyzed after $\mathrm{TiO}_{2}$ $(0.04 \mathrm{mg} / \mathrm{ml})$ and DNCB $(0.1 \%)$ treatment.

Injection of NPs in AOO-treated control mice did not have any effect on lymph node (LN) proliferation. DNCB sensitization resulted in $L N$ proliferation, which was further increased by injection of $\mathrm{TiO}_{2} \mathrm{NPs}$ before DNCB sensitization. The $\mathrm{EC}_{3}$ of DNCB, with prior injection of vehicle control was $0.041 \%$, while injection with $\mathrm{TiO}_{2}$ decreased the $\mathrm{EC}_{3}$ of DNCB to $0.015 \% . \mathrm{TiO}_{2} \mathrm{NPs}$ pre-treatment did not alter the lymphocyte subpopulations, but significantly increased the level of IL-4 and decreased IL-10 production in DNCB treated animals. In conclusion, our study demonstrates that administration of nano- $\mathrm{TiO}_{2}$ increases the dermal sensitization potency of DNCB, by augmenting a $\mathrm{Th}_{2}$ response, showing the immunomodulatory abilities of NPs.
\end{abstract}

Keywords: Nanoparticle, Titanium dioxide $\left(\mathrm{TiO}_{2}\right)$, Lymph node proliferation assay (LNPA), DNCB, Skin sensitization

\section{Background}

Nanoparticles of titanium dioxide $\left(\mathrm{TiO}_{2}\right)$ are one of the most abundantly produced and widely utilized nanomaterials [1], with applications in sunscreens, cosmetics, tooth pastes, and food products [2-4]. Other important industrial applications include water clean-up technology, oxygen sensor and antimicrobial coatings and ceramics. Titanium nanomaterials have proved their potentials in the fields of drug and gene delivery [2]. Although considered as an inert material, titanium alloys and implants have been shown to release both

\footnotetext{
* Correspondence: jeroen.vanoirbeek@med.kuleuven.be

${ }^{\dagger}$ Equal contributors

${ }^{2}$ Department of Public Health, Occupational, Environmental and Insurance Medicine, KU Leuven, Herestraat 49 bus 706, Leuven 3000, Belgium Full list of author information is available at the end of the article
}

micrometric and nanometric particles and debris in the surrounding body fluids and tissues which can cause health effects either at the implant site or in distant organs [5-8]. A variety of newly developed house hold products (including self-cleaning spray and paint) have been reported to contain $\mathrm{TiO}_{2} \mathrm{NPs}$. According to the Project on Emerging Nanotechnologies (Woodrow Wilson International Center for Scholars), as of $10^{\text {th }}$ of March 2011, 1317 consumer products containing NPs are already on the market and if the same trend persists this number is expected to reach 3400 by the year 2020 . $\mathrm{TiO}_{2}$ is the $3^{\text {rd }}$ largest material used in the consumer products.

Effects of NPs on biological systems are unknown or under debate $[9,10]$. Nevertheless, the widespread uses of $\mathrm{TiO}_{2}$ NPs confirm the possibilities of exposure through ingestion, inhalation and dermal routes. Taken

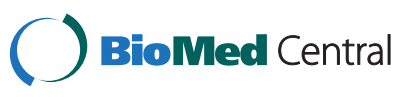


together with the substantial increase of products (in particular skin care products) containing $\mathrm{TiO}_{2}$ nanomaterials, there is an urgent need for assessing these newly developed materials for their possible skin sensitizing potentials as well as for their impact on the skin sensitization caused by the other chemicals.

Allergic skin sensitization caused by chemicals is a serious environmental and occupational health hazard. It is the most frequent manifestation of immunotoxicity in humans [11]. Literature reports identify more than 3700 chemical as skin sensitizers [12]. Based on positive skin sensitization tests in animals, it is predicted that in the near future an increase in the number of chemicals capable of causing contact dermatitis in humans will follow.

Dinitrochlorobenzene (DNCB) is a well-known skin sensitizer. It is the most used chemical to study contact hypersensitivity of the skin and the pathogenesis of contact dermatitis $[13,14]$. Contact dermatitis observed after DNCB application is a T-cell mediated immune response [15]. DNCB formed covalent complexes with various proteins after topical application and act as immunogen which are taken up by antigen presenting cells (APC), processed and presented to T cells for activation.

The Local Lymph Node Assay (LLNA) is an OECD approved protocol to assess dermal sensitizing capacity of chemicals (OECD guideline no. 429, 2002) [16]. A modified version of this test, lymph node proliferation assay (LNPA), has recently been suggested as more appropriate test methodology for the evaluation of NP induced delayed type hypersensitivity reaction $[17,18]$. The major advantage of LNPA/LLNA includes the possibility to calculate chemicals relative potency of inducing dermal sensitization.

The aim of this study was to evaluate the effect of a prior administration of $\mathrm{TiO}_{2}$ NPs on the dermal sensitization potential of DNCB. We hypothesized that $\mathrm{TiO}_{2}$ NPs might act as an adjuvant for a skin sensitizer, such as DNCB. To our knowledge, this is the first study to describe the effect of NPs on the dermal sensitization potential of a well-known chemical sensitizer.

\section{Results}

Figure 1 shows the details on the particle characteristics. Analysis of homogeneous suspensions of the NPs in $2.5 \mathrm{mM}$ sodium citrate by dynamic light scattering (DLS) showed two populations in the $\mathrm{TiO}_{2}$ samples. Primary $\mathrm{TiO}_{2}$ particles with a hydrodynamic diameter of $22 \mathrm{~nm}$ were detected next to aggregates with a mean hydrodynamic diameter of $272 \mathrm{~nm}$ (Figure 1A). Since larger particles scatter more photons than small particles, the intensity weighted distribution is favoured towards larger scatterers. On a number basis, $<0.01 \%$ of the particles were agglomerates or aggregates. On a mass basis, $23.8 \%$ of the mass was in agglomerates or aggregates. It shows that a significant number of $\mathrm{TiO}_{2}$ particles exist as primary particles in the suspension. The $\zeta$ potential for $\mathrm{TiO}_{2} \mathrm{NPs}$ in $2.5 \mathrm{mM}$ sodium citrate $(-52 \mathrm{mV})$ was significantly lower as compared to $\zeta$ potential in water $(-24 \mathrm{mV})$ (Figure $1 \mathrm{~A}$, inset). This lowered $\zeta$ potential as compared to that observed in water showed the stabilising effect of sodium citrate on NP suspensions. TEM analysis revealed a spherical morphology of $\mathrm{TiO}_{2} \mathrm{NPs}$ (Figure 1A, inset). For the pigment $\mathrm{TiO}_{2}$ particles, the DLS analysis also revealed two populations. A first population has an average diameter of $576 \mathrm{~nm}$, the second population has an average diameter of $76 \mathrm{~nm}$ (Figure 1B). The $\zeta$ potential for the pigment $\mathrm{TiO}_{2}$ particles in $2.5 \mathrm{mM}$ sodium citrate was $-22 \mathrm{mV}$ (Figure 1B, inset). The pigment particles also showed a rod-like morphology on TEM analysis (Figure 1B, inset).

Figure 2 shows the modulation effect of different doses of $\mathrm{TiO}_{2} \mathrm{NPs}$ on the dermal sensitization with DNCB. In AOO-treated control mice, a prior injection with $\mathrm{TiO}_{2}$ NP did not influence the SI. When $\mathrm{TiO}_{2}$ NPs were injected prior to DNCB sensitization, we found an increasing SI, compared to Veh injection prior to DNCB sensitization. This increased SI was statistically different using 0.04 and $0.4 \mathrm{mg} / \mathrm{ml} \mathrm{TiO}_{2}$ NPs prior to the $\mathrm{DNCB}$ sensitization. Injection of $0.04 \mathrm{mg} / \mathrm{ml}$ pigment $\mathrm{TiO}_{2}$ particles prior to DNCB sensitization was not significantly different from the group which received an injection with vehicle prior to DNCB sensitization. However, $\mathrm{TiO}_{2}$ pigment $(0.04 \mathrm{mg} / \mathrm{ml})$ injection prior to $\mathrm{DNCB}$ sensitization is statistically different from $\mathrm{TiO}_{2} \mathrm{NP}$ $(0.04 \mathrm{mg} / \mathrm{ml})$ injection prior to DNCB sensitization $(p<0.05$, not indicated in figure).

Figure 3 shows the effect of prior $\mathrm{TiO}_{2} \mathrm{NP}$ injection on the $\mathrm{EC}_{3}$ value of $\mathrm{DNCB}$ sensitization. Prior injection with vehicle (Veh), before sensitization with DNCB yielded an $\mathrm{EC}_{3}$ of $0.041 \%$, while injection with $\mathrm{TiO}_{2} \mathrm{NPs}(0.04 \mathrm{mg} / \mathrm{ml}$ i.e. $160 \mu \mathrm{g} / \mathrm{kg}$ ) before DNCB sensitization led to a shift to the left and resulted in an $\mathrm{EC}_{3}$ of $0.015 \%$.

In Table 1, the lymphocyte subpopulations of the auricular lymph nodes are presented. Mice subcutaneously injected with vehicle, followed by $0.1 \%$ DNCB sensitization showed significantly increased levels of $\mathrm{CD}^{+}$(T-cells), $\mathrm{CD}^{+} \mathrm{CD}^{+}$(T-helper cells), $\mathrm{CD}^{+} \mathrm{CD}^{+}$ $\mathrm{CD}_{25} 5^{+}$(activated/regulatory $\mathrm{T}$-cells), $\mathrm{CD}^{+} \mathrm{CD}^{+}$(Tcytotoxic cells) and $\mathrm{CD} 19^{+}$(B-cells) in the auricular lymph nodes. Prior injection of $0.04 \mathrm{mg} / \mathrm{ml} \mathrm{TiO} \mathrm{NP}_{2}$ before DNCB sensitization did not change the composition of the auricular lymph nodes compared to Veh/DNCB group.

Figure 4 shows the levels of cytokine production in cultured auricular lymphocytes, in the presence of ConA. Mice subcutaneously injected with vehicle, followed by $0.1 \%$ DNCB sensitization showed a significant increase in the level of IFN- $\gamma$ (Figure 4A), IL-10 
A

\begin{tabular}{|c|c|}
\hline Size (ø) $\mathrm{nm}^{\mathrm{a}}$ & $15-25$ \\
\hline Form & Spherical \\
\hline $\begin{array}{c}\text { Average } \\
\text { TEM Size } \\
(\mathrm{nm}+\mathrm{sd})\end{array}$ & $12 \pm 2$ \\
\hline $\begin{array}{c}\text { BET Surface } \\
\text { Area }\left(\mathrm{m}^{2} \cdot \mathrm{g}^{-1}\right)^{\mathrm{a}}\end{array}$ & 210 \\
\hline $\begin{array}{c}\text { Zeta Potential } \\
(\mathrm{mV})\end{array}$ & -52 \\
\hline $\begin{array}{c}\text { Hydrodynamic } \\
\text { Diameter (nm) }\end{array}$ & 22 and 272 \\
\hline $\begin{array}{c}\text { Crystalline } \\
\text { Structure }\end{array}$ & Anatase \\
\hline $\begin{array}{c}\text { Manufacturing } \\
\text { Process }\end{array}$ & Sol Gel Process \\
\hline $\begin{array}{c}\text { Surface } \\
\text { Modifications }\end{array}$ & Non \\
\hline $\begin{array}{c}\text { Impurities } \\
\text { a } \\
\text { (\% basis) }\end{array}$ & 0.3 \\
\hline
\end{tabular}

a Manufacturer's data
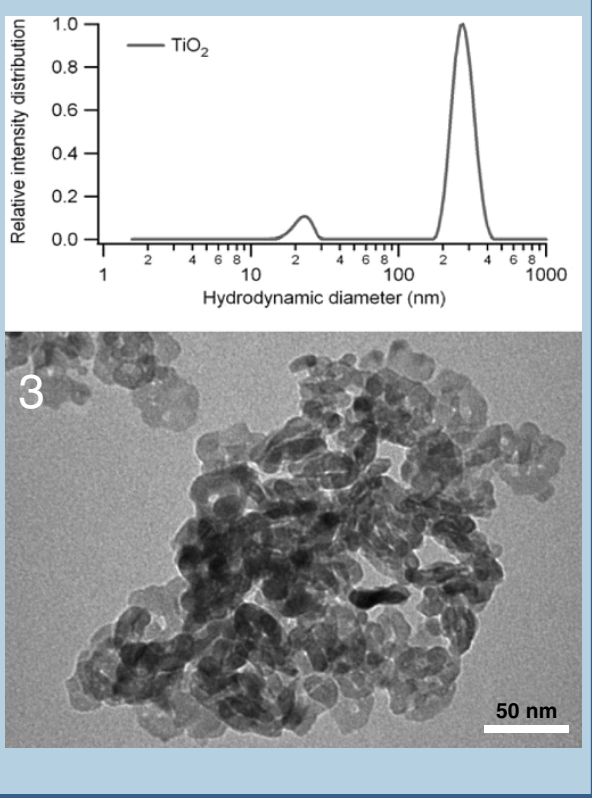

B

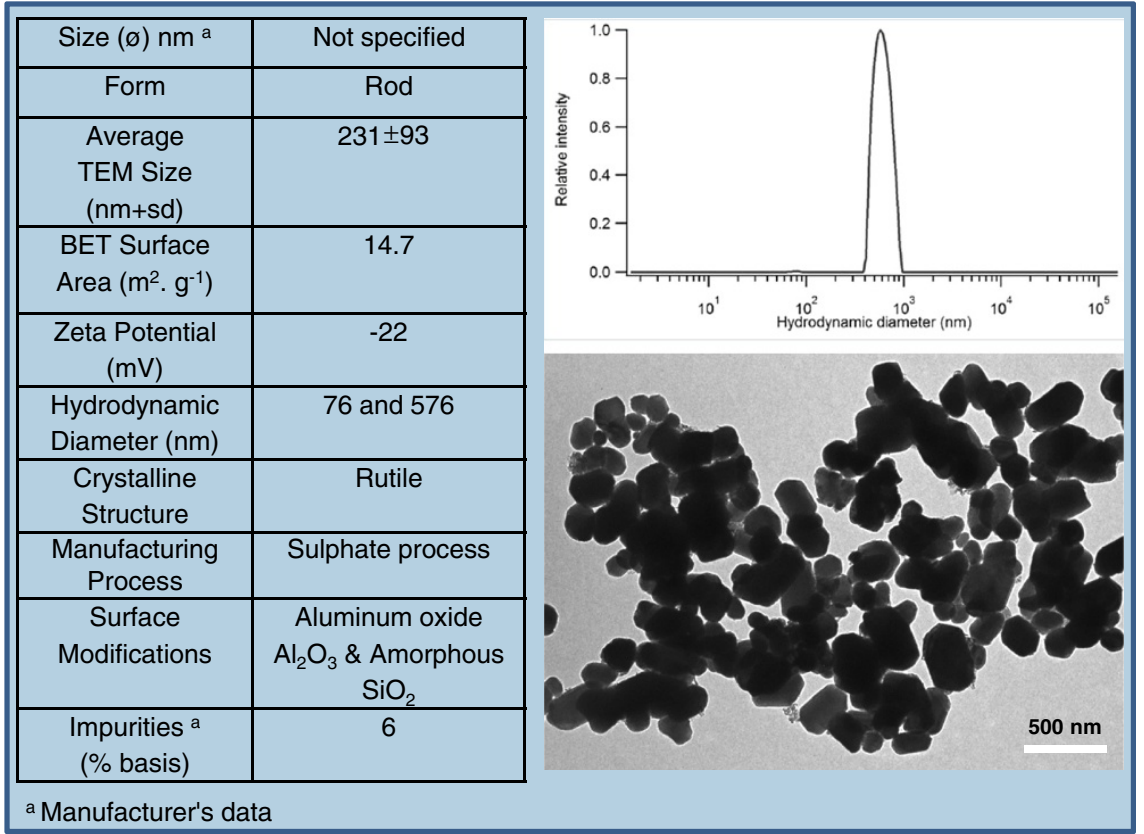

Figure 1 Physico-chemical characteristics of $\mathrm{TiO}_{2}$ nano (A) and pigment (B) particles in powder and suspension.
(Figure 4B) and IL-13 (Figure 4C) compared to Veh/ AOO group. When the mice were injected with $0.04 \mathrm{mg} / \mathrm{ml} \mathrm{TiO}_{2} \mathrm{NPs}$ before DNCB sensitization, the level of IL-4 (Figure 4D) was also significantly increased, while the level of IL-10 was decreased, but still significantly higher than non-sensitized $\mathrm{TiO}_{2} \mathrm{NP}$ treated mice. The levels of IFN- $\gamma$ and IL-13 were unchanged by $\mathrm{TiO}_{2}$ NP injection before DNCB sensitization. IL-2 and IL-17 levels were in all groups the same (data not shown).

\section{Discussion}

Our objective was to evaluate the effects of non-biodegradable/biopersistant solid $\mathrm{TiO}_{2} \mathrm{NPs}$ on the classical hypersensitivity reaction to a well-known potent dermal sensitizer (DNCB). To the best of our knowledge, there is no information available on the effect of manufactured NPs on the dermal sensitization potential of chemicals, in general, and of DNCB in particular. Recently, sensitizing potentials of biodegradable particles (ethosomes) 


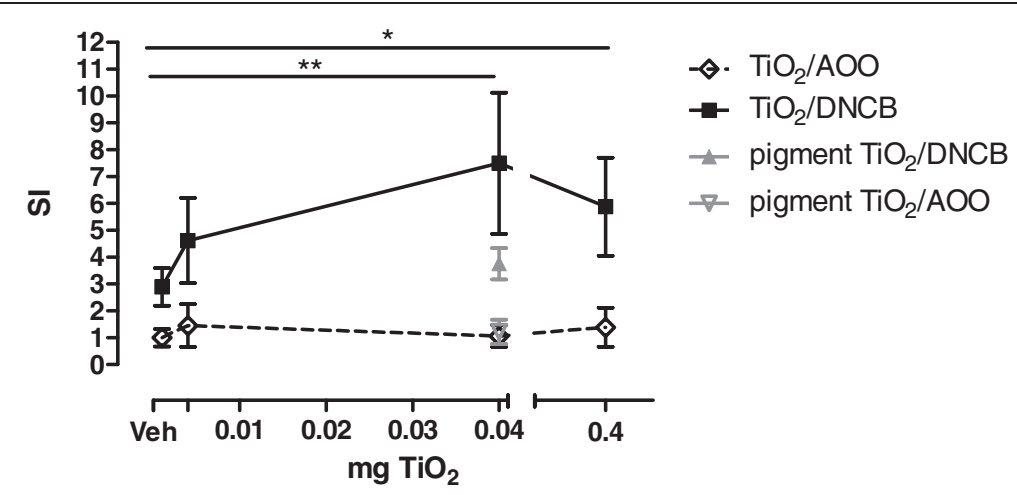

Figure 2 Effect of subcutaneous injections of $\mathrm{TiO}_{2} \mathrm{NPs}$ or pigment particles on the skin sensitizing capacity of $0.1 \%$ DNCB. Stimulation Index in lymph node proliferation assay (LNPA). To calculate the SI, all Sl's of the AOO-treated were pooled, since they were not statistically different from each other. Graph shows mean $\pm \mathrm{SD}, \mathrm{n}=5-9,{ }^{*} p<0.05$ and ${ }^{* *} p<0.01$.

was described, but such information about environmentally relevant solid NPs is lacking [19-21]. Here we demonstrate that $\mathrm{TiO}_{2}$ NPs $(0.04 \mathrm{mg} / \mathrm{ml})$ act as an immune-stimulator on the dermal sensitization capacity of DNCB. The stimulation of the dermal sensitization was coupled with a significant change in cytokine release which corresponds with the induction of a Th2 response. The experiments confirmed our hypothesis that pretreatment with $\mathrm{TiO}_{2}$ NPs modulate sensitization to DNCB.

There is conflicting evidence about the skin penetration of nanomaterials [22,23]. However, it has been suggested that NPs could pass through the stratum corneum of the skin using intercellular channels or hair follicles and penetrate into deeper skin layers [24,25]. A thorough search of the available literature indicates that stratum corneum is an effective barrier against the uptake of $\mathrm{TiO}_{2}$ NPs in healthy skin. However, various research publications anticipate the possibility of penetration of $\mathrm{TiO}_{2}$ NPs to the deeper layers of skin/viable skin in case of local damage (sun burns etc) or when lipid vesicles formulations are involved $[19,20,26]$. For example, a sub-erythemal dose ultraviolet radiation exposure (UVB $270 \mathrm{~mJ} / \mathrm{cm}^{2}$ ) in mice has been shown to allow the penetration of $45 \mathrm{~nm}$ quantum dot NPs to deep dermis [27]. In another study, it has been observed that $7 \mathrm{~nm} \mathrm{TiO}_{2} \mathrm{NP}$ exposure with UV irradiation can lead to increased skin barrier dysfunction and possible aggravation of contact dermatitis due to increased invasion of Staphylococcus aureus [28]. Interestingly, people tend to apply more sun screens containing NPs in case they have damaged skin (sunburns, burns) when the barrier function of skin is already impaired. It has also been reported that in a skin barrier dysfunction conditions (mite allergen exposure) intradermal exposure to rutile $\mathrm{TiO}_{2}$ NPs can lead to aggravation of the atopic skin lesions [29]. Particles which penetrate normal or damaged skin are taken up by antigen presenting cells

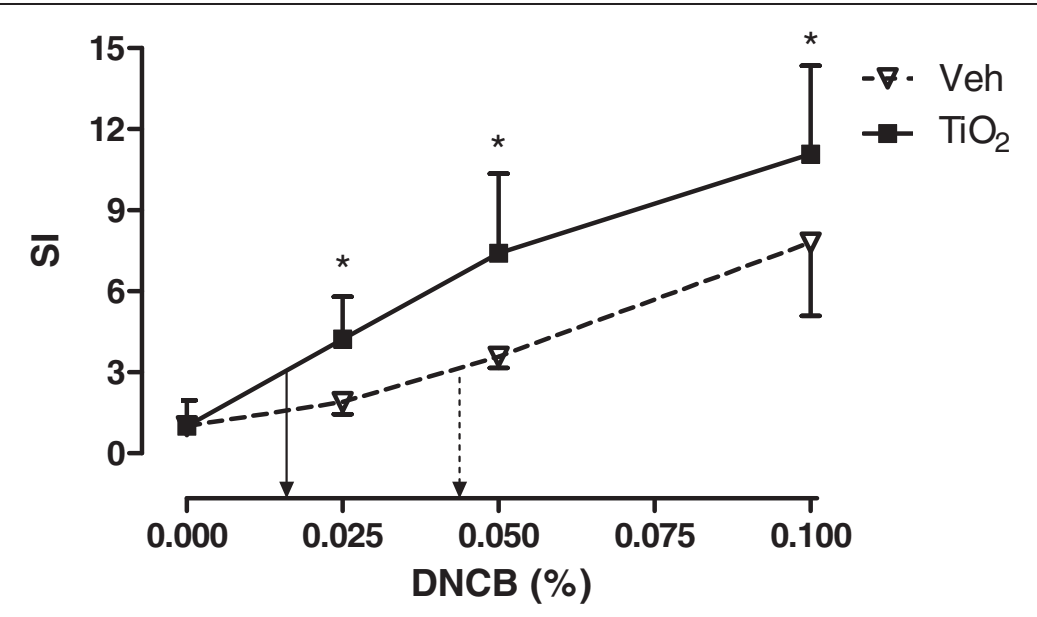

Figure 3 Effect of subcutaneous injections of $0.04 \mathrm{mg} / \mathrm{mlTiO}_{2} \mathrm{NPs}$ on the dose-response curve (SI) of DNCB sensitization. Mice were exposed to different doses of DNCB in the presence or absence of TiO2 NP pre-treatment $(0.04 \mathrm{mg} / \mathrm{ml})$. The EC 3 value of Veh/DNCB is $0.041 \%$ $(\rightarrow)$, while the $\mathrm{EC}_{3}$ of $\mathrm{TiO} 2 / \mathrm{DNCB}$ is $0.015 \%(\rightarrow)$. Graph shows mean $\pm \mathrm{SD}, \mathrm{n}=5-9,{ }^{*} p<0.05$. 
Table 1 Lymph node cell subpopulations $\left(\times 10^{6}\right)$ per lymph node

\begin{tabular}{lllll}
\hline & Veh/AOO & Veh/DNCB & $\mathrm{TiO}_{2} / \mathrm{AOO}$ & $\mathrm{TiO}_{2} / \mathrm{DNCB}$ \\
\hline $\mathrm{CD3}^{+}$ & $0.66 \pm 0.21$ & $2.06 \pm 0.56^{* * *}$ & $1.16 \pm 0.57$ & $2.27 \pm 0.59^{+++}$ \\
$\mathrm{CD3}^{+} \mathrm{CD}^{+}$ & $0.47 \pm 0.15$ & $1.47 \pm 0.41^{* * *}$ & $0.81 \pm 0.38$ & $1.56 \pm 0.43^{+++}$ \\
$\mathrm{CD3}^{+} \mathrm{CD}^{+} \mathrm{CD}^{+} 5^{+}$ & $0.04 \pm 0.01$ & $0.16 \pm 0.05^{* * *}$ & $0.06 \pm 0.03$ & $0.13 \pm 0.02^{++}$ \\
$\mathrm{CD3}^{+} \mathrm{CD}^{+}$ & $0.18 \pm 0.06$ & $0.59 \pm 0.15^{* * *}$ & $0.34 \pm 0.20$ & $0.68 \pm 0.19^{+++}$ \\
$\mathrm{CD}^{+} 9^{+}$ & $0.12 \pm 0.04$ & $0.62 \pm 0.22^{* * *}$ & $0.23 \pm 0.13$ & $0.80 \pm 0.30^{++}$ \\
\hline
\end{tabular}

Results are expressed as mean $\pm S D, n=9-11$, *** $p<0.001$ Veh/DNCB vs Veh/ AOOand ${ }^{++} p<0.01,{ }^{++} p<0.001 \mathrm{TiO}_{2} / \mathrm{DNCB}$ vs. $\mathrm{TiO}_{2} / \mathrm{AOO}$.

(APC), such as Langerhans cells or dendritic cells, and subsequently removed via the lymphatic system $[9,30]$. In view of these considerations, along with the possibility of exposure in individuals with pathological lesions of the skin, subcutaneous route becomes a relevant route to study NP induced effects on dermal sensitization. $\mathrm{TiO}_{2} \mathrm{NP}$ concentrations used in this study are based on literature reports by us and others describing these as non-cytotoxic concentrations in vitro and in vivo
[31,32]. Moreover, we did not observe any type of local injury around the site of injection of NPs.

Our results indicate that $\mathrm{TiO}_{2}$ NPs do not show dermal sensitization potential after a single subcutaneous injection, which is in accordance with findings in literature [32]. However, subcutaneous presence of $\mathrm{TiO}_{2} \mathrm{NPs}$ significantly increases the skin sensitization potential of DNCB, which is not the case with subcutaneous presence of pigment $\mathrm{TiO}_{2}$ particles before dermal sensitization. It is possible that increased sensitization after NP exposures is due to binding of the antigen with the NPs, leading to formation of depot of antigen which is better recognized by skin APCs. It has been proposed that ultrafine $\mathrm{TiO}_{2}$ particles (below $30 \mathrm{~nm}$ ) bind more ovalbumin per mass unit than fine particles and this binding may lead to a depot of antigen leading to increased antigenicity [33]. Moreover, it is a well accepted fact that professional APCs are more readily stimulated by the particulate antigens, thus adsorption of antigen per se can increase the antigenicity [34]. Other possible explanation might be physical interactions between the
A

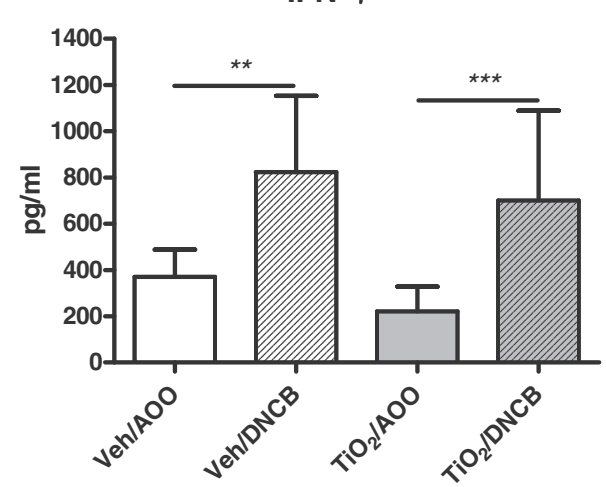

C

IL-13

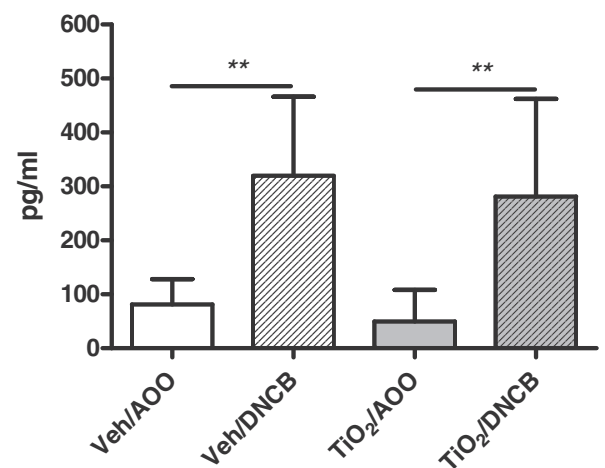

B IL-10

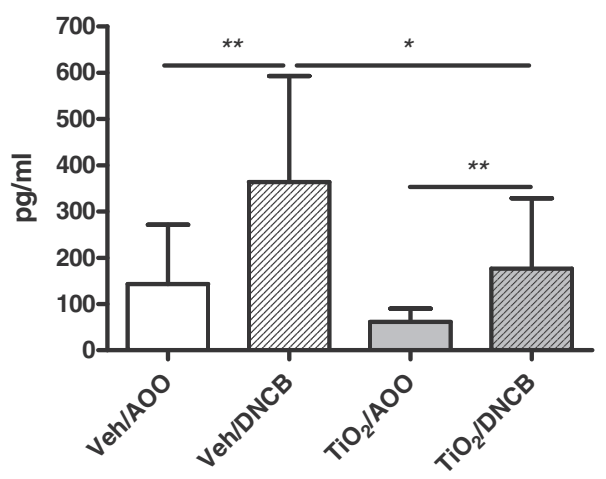

D

IL-4

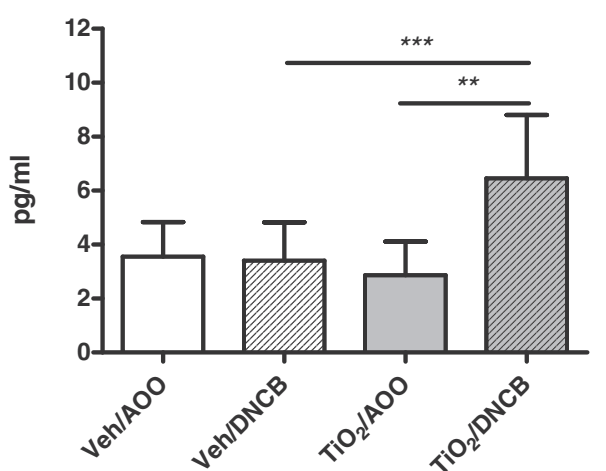

Figure 4 Lymphocyte cytokine production after $0.1 \%$ DNCB dermal sensitization or AOO treatment with prior injection of $0.04 \mathrm{mg} / \mathrm{ml}$ $\mathrm{TiO} 2$ or vehicle. On day 5, the auricular lymph nodes are removed and lymphocytes are cultured for $42 \mathrm{~h}$ in the presence of ConA. Cytokines are determined in LNC supernatant. Graphs show mean $\pm S D, n=10-12,{ }^{*} p<0.05,{ }^{* *} p<0.01$ and ${ }^{* * *} p<0.001$. 
NPs and APCs. Impurities cannot be a confounding factor in our experiments as there were no detectable amounts present in $\mathrm{TiO}_{2}$ NPs utilized in this study.

The results of the present study demonstrate that preexposure to $\mathrm{TiO}_{2}$ NPs does not interfere with the immune system if followed by a sham dermal treatment ( $\left.\mathrm{TiO}_{2} / \mathrm{Veh}\right)$. However, when pre-exposure to $\mathrm{TiO}_{2} \mathrm{NPs}$ is followed by DNCB sensitization, a Th2 favoured immune response in regional lymph node cells develops, with increased IL-4 and decreased IL-10 levels, while DNCB itself is a known potent Th1 responder [35]. The apparent IFN- $\gamma$ secretion confirms the DNCB-induced Th1 response, even with prior injection of $\mathrm{TiO}_{2}$ NPs. Nevertheless, $\mathrm{TiO}_{2}$ NPs injection followed by $\mathrm{DNCB}$ sensitization results in significantly increased levels of IL-4, demonstrating Th2 stimulation. In addition, we found a decrease in IL-10 secretion. IL-10 is a cytokine released by several cell types, such as monocytes, activated T cells, Th2 cells, mast cells and regulatory T cells. IL-10 is capable of inhibiting pro-inflammatory responses and is suggested to play a major role in maintenance of self-tolerance [36]. We think that subcutaneous exposure to $\mathrm{TiO}_{2}$ in DNCB sensitized mice, decreased IL-10, and thereby allowing the development of a Th2 response, independent of the presence of the Th1 response (levels of IFN- $\gamma$ are maintained).

Allergic sensitization reactions are the first step against the "foreign" materials, and are either Th1 or Th2 polarized. It has been shown that particles themselves can act as modulating agents in skewing the Th responses. Impact of particles on the skewing of Th response is largely dependent on the chemical nature and characteristics of the materials. Larsen et al, found that $\mathrm{TiO}_{2}$ NPs promote allergic sensitization to ovalbumin (IgE and IgG1 levels) and thus primes a Th2 dominated immune response [33]. Diesel exhaust can promote both Th1 and Th2 responses [37,38]. Carbon nanotubes either amplify Th1 (MWCNT) or Th2 (SWCNT) or both (MWCNT) responses $[39,40]$. These studies are done in the models of respiratory allergy using ovalbumin as sensitizing agent. However, respiratory allergic responses have already been shown to be more prone to Th2 skewing while skin sensitization responses are mostly Th1 dependent $[41,42]$. It is interesting to note that although we observe a skewing of immune response towards Th2 we still observe a shift in the potency of DNCB, with almost a 3-fold fold decrease in $\mathrm{EC}_{3}$.

\section{Conclusion}

In conclusion, we have demonstrated that $\mathrm{TiO}_{2} \mathrm{NPs}$ are effective in modulating the chemical-induced in vivo dermal sensitization. They probably act as adjuvant to increase the dermal sensitization capacity of a model chemical skin sensitizer (DNCB). These findings will be helpful in understanding the NPs induced health effects and will help in understanding the interactions of NPs with other sensitizing agents.

\section{Methods \\ Reagents}

2,4-Dinitrochorobenzene was purchased from SigmaAldrich (Bornem, Belgium). Trichloroacetic acid (TCA) and acetone were obtained from Sigma-Aldrich (Bornem, Belgium). Pentobarbital (Nembutal) was obtained from Sanofi Santé Animale (CEVA, Brussels, Belgium). Acetone-olive oil vehicle (AOO) used to dissolve DNCB was composed of a mixture of 4 volumes of acetone and 1 volume of olive oil (Selection de Almazara, Carbonell, Madrid, Spain). DNCB concentration is given as percent $(\mathrm{w} / \mathrm{v})$ in AOO. Hanks Balanced Salt solution (HBSS) was purchased from Invitrogen (Merelbeke, Belgium) and [Methyl-3 H]-thymidine $\left({ }^{3} \mathrm{HTdR}\right)$ was purchased from ICN Pharmaceuticals (Asse, Belgium).

\section{Nanoparticles}

$\mathrm{TiO}_{2}$ NPs (99.9\% anatase) of 10-25 nm diameter (15 nm average diameter) were purchased from Sigma-Aldrich (Saint Quentin Fallavier, France). These particles were prepared by sol-gel process and were used without any post production surface treatments/modifications. Pigment $\mathrm{TiO}_{2}$ was purchased from Cinkarna (Celje, Slovenia). Freshly prepared NPs suspensions at desired concentrations in $2.5 \mathrm{mM}$ sodium Citrate were utilized to treat the mice.

\section{Physico-chemical Characterization of NPs Dynamic Light Scattering}

DLS analysis of $\mathrm{TiO}_{2}$ pigment and NPs was performed according to the protocol described by us previously [43]. Briefly $\mathrm{TiO}_{2}$ pigment and NPs were diluted in $2.5 \mathrm{mM}$ sodium citrate $(\mathrm{pH}$ 6.95, ionic strength (I) $515 \mathrm{mM}$ ), ultrasonicated and analyzed using Brookhaven 90 Plus instrument (scattering angle: $90^{\circ}$, wavelength: $659 \mathrm{~nm}$, power $15 \mathrm{~mW}$ ). Correlation functions were analyzed with the Clementine package (maximum entropy method) for Igor Pro 6.02A. This resulted in intensity weighted distribution functions versus decay times. By converting the decay times with instrument parameters and physical parameters to hydrodynamic diameters, an intensity weighted size distribution was obtained. A lognormal fit was applied on each population resulting in the average hydrodynamic diameter of the population.

\section{Zeta Potential ( $\zeta$ ) Measurements}

Detailed protocol of $\zeta$ potential measurement is published elsewhere [43] was measured with a Brookhaven 90Plus/ZetaPlus instrument applying electrophoretic light scattering. A primary and reference beam (659 nm, 
$35 \mathrm{~mW}$ ), modulated optics and a dip-in electrode system were used. The frequency shift of scattered light (relative to the reference beam) from a charged particle moving in an electric field is related to the electrophoretic mobility of the particle. The Smoluchowski limit was used to calculate the zeta potential from the electrophoretic mobility.

\section{Transmission electron microscopy (TEM)}

Suspensions of the $\mathrm{TiO}_{2}$ particles were applied on formvar-coated cupper mesh grids. After drying overnight, the NPs were characterized by transmission electron microscopy (TEM) (JEOL JEM-1200 EX-II, Tokyo, Japan) at a magnification of 20.000-200.000 x.

\section{Mice}

Male BALB/c mice (approximately 20 g, 6 weeks old) were obtained from Harlan (Horst, The Netherlands). The mice were housed in a conventional animal house with 12-hour dark/light cycles. They were housed in plastic cages with filter tops and received lightly acidified water and pelleted food (Trouw Nutrition, Gent, Belgium) ad libitum. All experimental procedures were approved by the local Ethical Committee for Animal Experiments.

\section{Lymph Node Proliferation Assay (LNPA)}

LNPA was performed according to the method described previously $[17,18]$. Briefly, one hour prior to dermal sensitization, on day 0 , mice (5-9 animals per group) were injected sub-cutaneously with NP suspension or vehicle (Veh) (2.5 mM sodium Citrate) on the area medial to the implantation of each ear lobe. Subsequently, on days 0,1 and 2, the mice were given dermal applications $(25 \mu \mathrm{l}$ on each ear) of DNCB in AOO, or AOO alone. On day 5, the mice were injected intravenously in a tail vein with $250 \mu \mathrm{l}$ of $20 \mu \mathrm{Ci}{ }^{3} \mathrm{HTdR}$ solution in HBSS ( $\mathrm{pH}$ 7.2). Five hours later, the mice were sacrificed by an overdose of Nembutal $(90 \mathrm{mg} / \mathrm{kg}$ ) and auricular lymph nodes were removed, pooled and weighed. A single cell suspension of lymph node cells (LNC) was prepared and LNC were washed two times with HBSS. Subsequently, the LNC were dissolved in 5\% TCA and kept overnight at $4{ }^{\circ} \mathrm{C}$. ${ }^{3} \mathrm{HTdR}$ incorporation was evaluated by $\beta$-scintillation counting (Beckman LS 5000CE) and was expressed as disintegrations per minute ( $\mathrm{dpm})$. The stimulation index (SI) was calculated as a ratio of ${ }^{3} \mathrm{HTdR}$ incorporation in lymphocytes from DNBCtreated mice and AOO-treated controls. A compound having $\mathrm{SI}>3$ is considered to be a biologically relevant dermal sensitizer.

a) In a first experiment, mice were subcutaneously injected with $2 \times 50 \mu$ l of a 0.004 (low dose), 0.04 (medium dose) or 0.4 (high dose) $\mathrm{mg} / \mathrm{ml} \mathrm{NP}$ suspension, 0.04 (medium dose) $\mathrm{mg} / \mathrm{ml}$ pigment particles or vehicle on the area medial to the implantation of ear lobes. One hour later, the mice were dermally treated on both ears with $(25 \mu \mathrm{l})$ of $0.1 \%$ DNCB in AOO, or AOO alone and this for 3 consecutive days. On day 5, the LNPA was performed and the SI calculated.

b) In a second experiment, mice were subcutaneously injected with $2 \times 50 \mu \mathrm{l}$ of 0.04 (medium dose) $\mathrm{mg} / \mathrm{ml}$ NP suspension or vehicle on the area medial to the implantation of ear lobes. Afterwards, the mice were treated on each ear with $\mathrm{DNCB}(0.025,0.050$ or $0.1 \%$ ) in $\mathrm{AOO}$, or $\mathrm{AOO}$ alone, for 3 consecutive days. On day 5 , the LNPA was performed, the SI calculated, from which the $\mathrm{EC}_{3}$ (effective concentration yielding a Si of 3) was determined.

\section{Lymph node cell analysis}

In a separate group of animals, mice received an NP injection with $0.04 \mathrm{mg} / \mathrm{ml} \mathrm{TiO}_{2}$ or vehicle and were afterwards dermally treated for three consecutive days with $0.1 \%$ DNCB sensitization in AOO, or AOO alone, but on day 5 no ${ }^{3} \mathrm{HTdR}$ was injected and lymph node cells were isolated. The lymph nodes were kept on ice in RPMI-1640 (Invitrogen, Merelbeke, Belgium) and cell suspensions were obtained by pressing the lymph nodes through a cell strainer $(100 \mu \mathrm{m})$ (BD Bioscience, Erembodegem, Belgium) and rinsing with $10 \mathrm{ml}$ RPMI-1640. Cells were counted using a Bürker hemocytometer. Lymphocytes were washed three times and suspended $\left(10^{7}\right.$ cells $\left./ \mathrm{ml}\right)$ in complete tissue culture medium (RPMI-1640 supplemented with 10\% heat-inactivated fetal bovine serum, $10 \mathrm{mg} / \mathrm{ml}$ streptomycin and $100 \mathrm{IU} /$ $\mathrm{ml}$ penicillin).

a) Cell subpopulation analysis:

We stained $5 \times 10^{5}$ cells with either anti-CD3+ (APC, T-lymphocytes), anti-CD4+ (APC-Cy7, Th-lymphocytes), anti-CD8+ (PerCP-Cy5.5, Tc-lymphocytes) and anti-CD25+ (PE, activated/ regulatory T-lymphocytes) antibodies or with anti-CD19+ (PE, B-lymphocytes) labelled antibodies, according to manufacturer's instructions (BD Biosciences, Erembodegem, Belgium). All necessary controls (including isotype controls) were performed using isotype match control antibodies. Flow cytometry (FACSArray, BD Biosciences, Erembodegem, Belgium) was performed using at least $10^{5}$ cells.

b) Cytokine analysis:

Cells were seeded into 48-well culture plates at a density of 106 cells/ml and incubated in complete RPMI-1640 medium for $42 \mathrm{~h}$ containing $2.5 \mu \mathrm{g} / \mathrm{ml}$ 
concanavaline A (ConA) (Sigma-Aldrich, Bornem, Belgium). Culture supernatant was collected, centrifuged $\left(1000 \mathrm{~g}, 15\right.$ minutes at $\left.4^{\circ} \mathrm{C}\right)$ and stored at $-80^{\circ} \mathrm{C}$ till further analysis. Levels of IL-2, IL-4, IL-10, IL-13, IL-17 and interferon gamma (IFN- $\gamma$ ) were measured via Cytometric Bead Array and analyzed with the FCAP Array Software on the FACSArray (BD Biosciences, Erembodegem, Belgium). Lower detection limits were $0.2 \mathrm{pg} / \mathrm{ml}, 0.3 \mathrm{pg} / \mathrm{ml}, 9.6 \mathrm{pg} / \mathrm{ml}$, $2.4 \mathrm{pg} / \mathrm{ml}, 0.95 \mathrm{pg} / \mathrm{ml}$ and $0.5 \mathrm{pg} / \mathrm{ml}$, respectively.

\section{Statistical Analysis}

Data are presented as means and SD. All the data were $\log$ transformed for statistical analysis (Graphpad Prism 5.01, Graphpad Software, Inc, San Diego, CA). Data of Table 1, Figures 2 and 4 were analysed by a one-way ANOVA followed by Bonferroni post hoc test. In the post-hoc test, four different comparisons were performed: Veh/AOO vs. Veh/DNCB, Veh/AOO vs. $\mathrm{TiO}_{2} /$ AOO, $\mathrm{TiO}_{2} / \mathrm{AOO}$ vs. $\mathrm{TiO}_{2} / \mathrm{DNCB}$ and $\mathrm{Veh} / \mathrm{DNCB}$ vs. $\mathrm{TiO}_{2} / \mathrm{DNCB}$. Figure 3 was analysed using a two-way ANOVA followed by a bonferroni post hoc test, comparing Veh vs $\mathrm{TiO}_{2}$ injection prior to DNCB sensitization. A level of $p<0.05$ (two tailed) was considered as significant.

\section{Competing interests}

None of the authors have competing interests.

\section{Authors' contributions}

SH and SS were involved in setting up and performing the experiments, along with writing the manuscript. VDV and BE performed the experiments and read the manuscript. KVL performed TEM imaging. SB and FM are the promoter of $\mathrm{SH}$ and thoroughly read the manuscript. BN, $\mathrm{PH}$ and JV are the promoters of SS, BE and VDV. They came up with the idea for the experiment, initiated the set-up, read the manuscript and are responsible for its final version.

\section{Acknowledgements}

This work was supported by ANR grant nº 059 9-05 SET 024-01, ANR grant $n^{\circ} 06$ SEST 24-01, CAMPLP, Legs Poix, the Interuniversity Attraction Pole Program, Belgian State, Belgian Science Policy P6/35, from the 'Fonds voor Wetenschappelijk Onderzoek Vlaanderen' (FWO), FWO G.0547.08 and the EU-FP7 project "Nanohouse" Grant Agreement n²47810. J.V. and V.D are a post-doctoral fellow of the FWO.

\footnotetext{
Author details

'Unit of Functional and Adaptive Biology (BFA) CNRS EAC 4413, Laboratory of Molecular and Cellular Responses to Xenobiotics (RMCX), Univ Paris Diderot, Sorbonne Paris Cité, France. ${ }^{2}$ Department of Public Health,

Occupational, Environmental and Insurance Medicine, KU Leuven, Herestraat 49 bus 706, Leuven 3000, Belgium. ${ }^{3} \mathrm{KU}$ Leuven BIOMAT, Department of Oral Health Sciences, Conservative Dentistry, KU Leuven, Leuven, Belgium. ${ }^{4}$ Present Address: Clinical research unit, National Institute of Environmental Health Sciences (NIEHS)/National Institute of Health (NIH), Research Triangle Park, North Carolina, USA.
}

Received: 14 October 2011 Accepted: 2 May 2012

Published: 23 May 2012

\section{References}

1. Xia T, Kovochich M, Brant J, Hotze M, Sempf J, Oberley T, Sioutas C, Yeh Jl, Wiesner MR, Nel AE: Comparison of the abilities of ambient and manufactured nanoparticles to induce cellular toxicity according to an oxidative stress paradigm. Nano Lett 2006, 6:1794-1807.

2. Kaida T, Kobayashi K, Adachi M, Suzuki F: Optical characteristics of titanium oxide interference film and the film laminated with oxides and their applications for cosmetics. J Cosmet Sci 2004, 55:219-220.

3. Long TC, Tajuba J, Sama P, Saleh N, Swartz C, Parker J, Hester S, Lowry GV Veronesi B: Nanosize titanium dioxide stimulates reactive oxygen species in brain microglia and damages neurons in vitro. Environ Health Perspect 2007, 115:1631-1637.

4. Mani G, Johnson DM, Marton D, Feldman MD, Patel D, Ayon AA, Agrawal CM: Drug delivery from gold and titanium surfaces using self-assembled monolayers. Biomaterials 2008, 29:4561-4573.

5. Brien WW, Salvati EA, Betts F, Bullough P, Wright T, Rimnac C, Buly R, Garvin K: Metal levels in cemented total hip arthroplasty. A comparison of well-fixed and loose implants. Clin Orthop Relat Res 1992, 276:66-74.

6. Flatebo RS, Johannessen AC, Gronningsaeter AG, Boe OE, Gjerdet NR, Grung B, Leknes KN: Host response to titanium dental implant placement evaluated in a human oral model. $J$ Periodontol 2006, 77:1201-1210.

7. Frisken KW, Dandie GW, Lugowski S, Jordan G: A study of titanium release into body organs following the insertion of single threaded screw implants into the mandibles of sheep. Aust Dent J 2002, 47:214-217.

8. Torgersen S, Gjerdet NR, Erichsen ES, Bang G: Metal particles and tissue changes adjacent to miniplates. A retrieval study. Acta Odontol Scand 1995, 53:65-71.

9. Hoet PH, Bruske-Hohlfeld I, Salata OV: Nanoparticles - known and unknown health risks. J Nanobiotechnology 2004, 2:12.

10. Maynard AD, Aitken RJ, Butz T, Colvin V, Donaldson K, Oberdorster G, Philbert MA, Ryan J, Seaton A, Stone V, et al: Safe handling of nanotechnology. Nature 2006, 444:267-269.

11. Lalko JF, Kimber I, Dearman RJ, Gerberick GF, Sarlo K, Api AM: Chemical reactivity measurements: potential for characterization of respiratory chemical allergens. Toxicol In Vitro 2011, 25:433-445.

12. van Loveren H, Cockshott A, Gebel T, Gundert-Remy U, de Jong WH, Matheson J, McGarry H, Musset L, Selgrade MK, Vickers C: Skin sensitization in chemical risk assessment: report of a WHO/IPCS international workshop focusing on dose-response assessment. Regul Toxicol Pharmacol 2008, 50:155-199.

13. Garrigue JL, Nicolas JF, Fraginals R, Benezra C, Bour H, Schmitt D: Optimization of the mouse ear swelling test for in vivo and in vitro studies of weak contact sensitizers. Contact Dermatitis 1994, 30:231-237.

14. Zhang EY, Chen AY, Zhu BT: Mechanism of dinitrochlorobenzene-induced dermatitis in mice: role of specific antibodies in pathogenesis. PLOS One 2009, 4:e7703.

15. Watanabe H, Unger M, Tuvel B, Wang B, Sauder DN: Contact hypersensitivity: the mechanism of immune responses and $T$ cell balance. J Interferon Cytokine Res 2002, 22:407-412.

16. Kimber I, Hilton J, Weisenberger C: The murine local lymph node assay for identification of contact allergens: a preliminary evaluation of in situ measurement of lymphocyte proliferation. Contact Dermatitis 1989, 21:215-220.

17. Dobrovolskaia MA, Germolec DR, Weaver JL: Evaluation of nanoparticle immunotoxicity. Nat Nanotechnol 2009, 4:411-414.

18. Weaver JL, Chapdelaine JM, Descotes J, Germolec D, Holsapple M, House R, Lebrec $\mathrm{H}$, Meade J, Pieters R, Hastings KL, et al: Evaluation of a lymph node proliferation assay for its ability to detect pharmaceuticals with potential to cause immune-mediated drug reactions. J Immunotoxicol 2005, 2:11-20.

19. Simonsson C, Madsen JT, Graneli A, Andersen KE, Karlberg AT, Jonsson CA, Ericson MB: A study of the enhanced sensitizing capacity of a contact allergen in lipid vesicle formulations. Toxicol Appl Pharmacol 2011, 252:221-227.

20. Madsen JT, Vogel S, Johansen JD, Andersen KE: Encapsulating contact allergens in liposomes, ethosomes, and polycaprolactone may affect their sensitizing properties. Cutan Ocul Toxicol 2011, 30:116-123.

21. Madsen JT, Vogel S, Johansen JD, Sorensen JA, Andersen KE, Nielsen JB: Percutaneous penetration characteristics and release kinetics of contact allergens encapsulated in ethosomes. Cutan Ocul Toxicol 2011, 30:38-44.

22. Schulz J, Hohenberg H, Pflucker F, Gartner E, Will T, Pfeiffer S, Wepf R, Wendel V, Gers-Barlag H, Wittern KP: Distribution of sunscreens on skin Adv Drug Deliv Rev 2002, 54(Suppl 1):S157-S163. 
23. Lademann J, Weigmann $H$, Rickmeyer $\mathrm{C}$, Barthelmes $\mathrm{H}$, Schaefer $\mathrm{H}$, Mueller G, Sterry W: Penetration of titanium dioxide microparticles in a sunscreen formulation into the horny layer and the follicular orifice. Skin Pharmacol Appl Skin Physiol 1999, 12:247-256.

24. Liang XJ, Chen C, Zhao Y, Jia L, Wang PC: Biopharmaceutics and therapeutic potential of engineered nanomaterials. Curr Drug Metab 2008, 9:697-709.

25. Patlolla RR, Desai PR, Belay K, Singh MS: Translocation of cell penetrating peptide engrafted nanoparticles across skin layers. Biomaterials 2010, 31:5598-5607.

26. Johnston HJ, Hutchison GR, Christensen FM, Peters S, Hankin S, Stone V: Identification of the mechanisms that drive the toxicity of $\mathrm{TiO}(2)$ particulates: the contribution of physicochemical characteristics. Part Fibre Toxicol 2009, 6:33.

27. Mortensen LJ, Oberdorster G, Pentland AP, Delouise LA: In vivo skin penetration of quantum dot nanoparticles in the murine model: the effect of UVR. Nano Lett 2008, 8:2779-2787.

28. Kambara T, Aihara M, Matsukura S, Sato I, Kubota Y, Hirasawa T, Ikezawa Z: Effects of photocatalytic agent on DS-Nh mice, developing atopic dermatitis-like eruption with an increase of Staphylococcus aureus. Int Arch Allergy Immunol 2006, 141:151-157.

29. Yanagisawa R, Takano H, Inoue K, Koike E, Kamachi T, Sadakane K, Ichinose $\mathrm{T}$ : Titanium dioxide nanoparticles aggravate atopic dermatitis-like skin lesions in NC/Nga mice. Exp Biol Med (Maywood) 2009, 234:314-322.

30. Hussain S, Vanoirbeek JA, Hoet PH: Interactions of nanomaterials with the immune system. Wiley Interdiscip Rev Nanomed Nanobiotechnol 2012, 4 (2):169-83

31. Hussain S, Boland S, Baeza-Squiban A, Hamel R, Thomassen LC, Martens JA, Billon-Galland MA, Fleury-Feith J, Moisan F, Pairon JC, et al: Oxidative stress and proinflammatory effects of carbon black and titanium dioxide nanoparticles: role of particle surface area and internalized amount. Toxicology 2009, 260:142-149.

32. Warheit DB, Hoke RA, Finlay C, Donner EM, Reed KL, Sayes CM: Development of a base set of toxicity tests using ultrafine $\mathrm{TiO} 2$ particles as a component of nanoparticle risk management. Toxicol Lett 2007, 171:99-110

33. Larsen ST, Roursgaard M, Jensen KA, Nielsen GD: Nano titanium dioxide particles promote allergic sensitization and lung inflammation in mice. Basic Clin Pharmacol Toxicol 2010, 106:114-117.

34. Chan RC, Wang M, Li N, Yanagawa Y, Onoe K, Lee JJ, Nel AE: Pro-oxidative diesel exhaust particle chemicals inhibit LPS-induced dendritic cell responses involved in T-helper differentiation. J Allergy Clin Immunol 2006, 118:455-465.

35. Dearman RJ, Warbrick EV, Skinner R, Kimber I: Cytokine fingerprinting of chemical allergens: species comparisons and statistical analyses. Food Chem Toxicol 2002, 40:1881-1892.

36. McGuirk P, Higgins SC, Mills KH: The role of regulatory T cells in respiratory infections and allergy and asthma. Curr Allergy Asthma Rep 2010, 10:21-28.

37. Takano H, Yoshikawa T, Ichinose T, Miyabara Y, Imaoka K, Sagai M: Diesel exhaust particles enhance antigen-induced airway inflammation and local cytokine expression in mice. Am J Respir Crit Care Med 1997, 156:36-42.

38. Yanagisawa R, Takano H, Inoue KI, Ichinose T, Sadakane K, Yoshino S, Yamaki K, Yoshikawa T, Hayakawa K: Components of diesel exhaust particles differentially affect Th1/Th2 response in a murine model of allergic airway inflammation. Clin Exp Allergy 2006, 36:386-395.

39. Inoue K, Koike E, Yanagisawa R, Hirano S, Nishikawa M, Takano H: Effects of multi-walled carbon nanotubes on a murine allergic airway inflammation model. Toxicol Appl Pharmacol 2009, 237:306-316.

40. Inoue K, Yanagisawa R, Koike E, Nishikawa M, Takano H: Repeated pulmonary exposure to single-walled carbon nanotubes exacerbates allergic inflammation of the airway: Possible role of oxidative stress. Free Radic Biol Med 2010, 48:924-934.

41. Kimber I, Dearman RJ: What makes a chemical a respiratory sensitizer? Curr Opin Allergy Clin Immunol 2005, 5:119-124.

42. Vanoirbeek JA, Tarkowski M, Vanhooren HM, De Vooght V, Nemery B, Hoet $\mathrm{PH}$ : Validation of a mouse model of chemical-induced asthma using trimellitic anhydride, a respiratory sensitizer, and dinitrochlorobenzene, a dermal sensitizer. J Allergy Clin Immunol 2006, 117:1090-1097.
43. Hussain S, Vanoirbeek JA, Luyts K, De Vooght V, Verbeken E, Thomassen LC, Martens JA, Dinsdale D, Boland S, Marano F, et al: Lung exposure to nanoparticles modulates an asthmatic response in a mouse model. Eur Respir J 2011, 37:299-309.

doi:10.1186/1743-8977-9-15

Cite this article as: Hussain et al:: Nano-titanium dioxide modulates the dermal sensitization potency of DNCB. Particle and Fibre Toxicology 2012 9:15.

\section{Submit your next manuscript to BioMed Central and take full advantage of:}

- Convenient online submission

- Thorough peer review

- No space constraints or color figure charges

- Immediate publication on acceptance

- Inclusion in PubMed, CAS, Scopus and Google Scholar

- Research which is freely available for redistribution 